\title{
Political Consequences of the Plague of Athens
}

\author{
Javier Martínez
}

\begin{abstract}
During the Plague of Athens, foreign refugees as well as inhabitants of nearby rural areas flooded the city, establishing the necessary conditions for the epidemic to spread rapidly to other parts of Greece. Athens, formerly Greece's most open and accepting city-state with regards to resident aliens ('metics'), experienced such disruption that metics would suffer permanent loss of the legal right to become Athenian citizens - while perhaps also losing the desire to seek citizenship - and Athens itself would suffer a permanent loss of power and prestige. Athenian attitudes toward metics did change noticeably in the fourth and fifth centuries, but not for the better.
\end{abstract}

\section{Keywords}

Plague of Athens; resident aliens in Athens; metics; women; xenophobia 


\section{Introduction}

The Plague of Athens (430-426 BCE) remains one of the most famous epidemics in history, even though only one eyewitness account, that of Athenian citizen Thucydides, survives (Salway \& Dell 1955). The epidemic erupted in Attica in the second year of the Peloponnesian War (431-404 BCE) during a siege of Athens (then the leader of the Delian League) by its rival city-state, Sparta, and Sparta's allies in the Peloponnesian League. When the disease first began to spread, Athens was crowded with foreign refugees and local inhabitants from the countryside. This increase in population overstretched the city's infrastructure and resources, and set up the conditions for an epidemic that spread easily to other parts of Greece. Athens did not fully recover from the plague for nearly a generation: the effects of the epidemic may have helped Athens to lose the Peloponnesian War, which permanently ended the city's hegemony and drastically reduced its power (Couch 1935). It is an irony, therefore, that the most open and accepting state in Greece of resident aliens (called 'metics') would experience such a calamity. Athenian attitudes toward metics did ultimately change in the fifth and fourth centuries, but not for the better.

\section{Thucydides' account of the Plague}

According to Thucydides' account, Athenians believed the plague had originated in North Africa (Ethiopia), and was transmitted via Persia in the second year of the war (430 BCE). The plague arrived in summer, during a siege laid by Sparta, in a year when Athens had otherwise experienced very little disease. The plague first struck the Athenian port-city of Piraeus, initially causing suspicion that the invading army had poisoned water-sources there. Then the disease struck again in 429, killing the Athenian general Pericles, ${ }^{1}$ and yet again in the winter of $427 / 6 .^{2}$

It remains unknown what exactly the disease was: there are almost thirty different theories about the pathogen (Morens \& Littman 1992). Some historians have even theorized that the account of the plague given by Thucydides was a fiction written long after the war (Longrigg 1980), not unlike Daniel Defoe's Journal of a Plague Year. ${ }^{3}$ Scientists generally speculate that it was typhus, measles or influenza, since these are all diseases that spread rapidly in close quarters and whose symptoms bear some resemblance to what is described by Thucydides. Other areas in the Mediterranean, including Lemnos and Rome, were struck by disease around the same time, possibly by the same pathogen. DNA analysis of dental pulp from a mass grave in Athens dated to that period implicates typhoid, a water-borne pathogen (Papagrigorakis et al. 2006).

1 Thucydides nowhere mentions that Pericles died from the plague. The notice of his death is found in Plutarch's Life of Pericles, Per. 38.

2 For Thucydides' account of the plague, see Thucydides 2.47-55.

3 For a comparison of the two accounts, see Rubincam (2004). 
It is not necessary for our purposes here to identify the precise pathogen: its general nature and mode of transmission are sufficient, and both are well established. The epidemic spread quickly from person to person and killed quickly - in about a week (Thuc. 2.49). ${ }^{4}$ The disease left its survivors weakened, it was not seasonal in character, and evidence suggests the possibility that it killed across species (Thuc. 2.50). The epidemic persisted off and on for over three years, during which time it killed a third of the city's population (Thuc. 3.87). The disease was new to the inhabitants, and infection appeared to confer immunity on survivors since it did not attack the same person twice (Thuc. 2.50). Thucydides himself was one of those who survived the infection (2.48). He observes that the plague hit the refugees from the countryside especially hard because they were crowded together in unsanitary conditions (Thuc. 2.52). The epidemic also weakened Athens' military strength at a time when the city needed it the most. This fact alone made it precisely the kind of plague that might terrify and disrupt a society and create social upheavals that could ultimately prove disastrous for vulnerable minority populations like the immigrant metic class.

Thucydides records a number of such social disruptions occasioned by the epidemic. Relatives and friends were afraid to bury their dead, for fear that they would also catch the pestilence. Dead bodies, and even the dying victims, were left untended and unburied, in violation of the strict Greek burial rites (Thuc. 2.52). Carrion birds and dogs appear to have avoided plague victims, or may indeed have suffered a population crash after initially feeding upon them (Thuc. 2.50). People ceased to fear laws because they

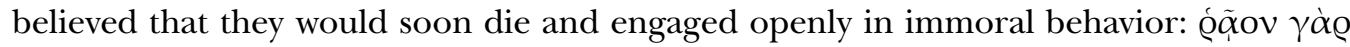

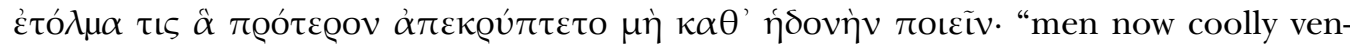
tured on what they had formerly done in a corner" (transl. Crawley). Belief in the gods - who were probably perceived as silent and unhelpful in these circumstances - waned: ${ }^{5}$

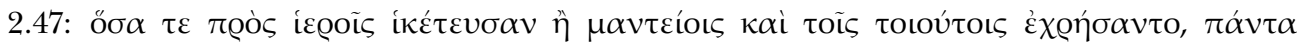

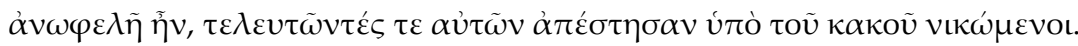

"Supplications in the temples, divinations, and so forth were found equally futile, till the overwhelming nature of the disaster at last put a stop to them altogether" (transl. Crawley).

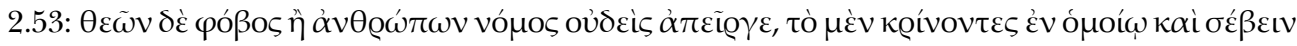

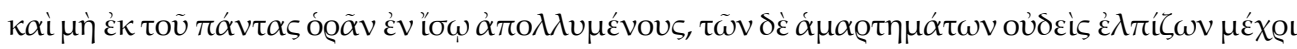

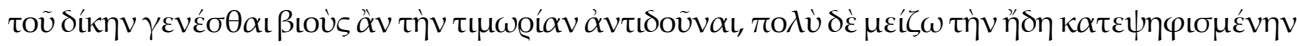

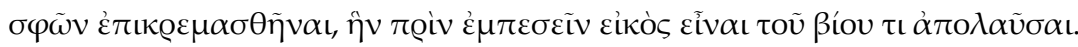

"Fear of gods or law of man there was none to restrain them. As for the first, they judged it to be just the same whether they worshipped them or not, as they saw all alike perishing; and for

4 But for Pericles as a slow-progress case, see Plut. Per. 38.1: "At this time, it would seem, the plague laid hold of Pericles, not with a violent attack, as in the case of others, nor acute, but one which, with a kind of sluggish distemper that prolonged itself through varying changes, used up his body slowly and undermined the loftiness of his spirit" (transl. Perrin).

5 But as Hornblower (1991: p. 319) notes "Th. is merely saying in rhetorical language that piety and religion were quite useless". 
the last, no one expected to live to be brought to trial for his offences, but each felt that a far severer sentence had been already passed upon them all and hung ever over their heads, and before this fell it was only reasonable to enjoy life a little" (transl. Crawley).

In fact, the only increase in religious activity was the popularization of claims that the gods were punishing Athens with the disease, like the belief which emerged holding that the god Apollo, a deity associated with pestilence, had sided with the Spartans (Thuc. 2.54). As for Athenian women, who had few rights and were kept segregated from men, they would experienced both more privation and also more freedom due to the war and the pestilence (Laurin 2005: pp. 162, 191).

Though Pericles in his famous funeral oration - which Thucydides records shortly before beginning his account of the plague - had praised Athenian women for not bringing shame on their men, it cannot be asserted that the increased freedom of women went unnoticed or was considered a positive change in Athens. Athenian legends of the warlike Amazons had already taken the concept of Barbarian enemies from the east in the fifth century, and gendered it as specifically female (Stewart 1995). In this respect, a rebellious woman during a siege could be perceived as an internal enemy, a threat on par with Barbarian invasion. Societal structures were restored after the plague receded, but Athenian society suffered permanent and lasting damage, which occasioned its gradual and irreversible decline from that point forward.

Much discussion has been occasioned by Thucydides' rhetorically dense, apparently precise, yet medically non-technical, language describing the course of the disease, and by the attempt to establish a precise translation of his terminology (Craik 2001; Parry 1969). ${ }^{6}$ The symptoms mentioned are not an exact match for any known epidemic disease. Some medical historians point to this as an example of a unique disease (or perhaps combination of diseases) that may then have mutated into forms more familiar to us in modern times (Holladay \& Poole 1979). Others question the faith placed by earlier scholars in the bona fides of Thucydides as a scientist, disputing both the accuracy and objectivity of his observations (Alford 1998). Though Thucydides claimed to be objective and uninterested in religious explanations, he focused more on the social disruptions of the plague - especially the alteration of social mores that had remained intact during the war - than on its physical depredations, suggesting a belief that these social disruptions endangered and vitiated Athenian society even more than the war itself, and ultimately proved more beneficial to the enemy (Orwin 1988). This debate is complicated by the fact that, while other ancient sources (most notably, the Roman writer, Lucretius, c.99c.55 BCE) mention the plague, their source is clearly the same as ours - Thucydides (Commager 1957). ${ }^{7}$ Thucydides' assertion that he, too, had suffered from the plague and survived it can be taken in support either of his objectivity - because he had personal experience with the disease and also how others responded to the afflicted - or of his

6 Parry (1969) notes that the language used in this passage by Thucydides is not very different from the one used by physicians of the period to their patients. Connor (1985: p. 58, n. 19), however, points out that "there are occasional signs of a Thucydidean utilization of the more unusual parts of medical vocabulary".

7 About the question of Lucretius' poem completion, see Butterfield (2014: pp. 20f. and n. 25). 
emotionalism, if his views are interpreted as having been clouded by personal trauma (Longrigg 1980).

We do know from Thucydides the conditions in the city of the time of the plague (severe overcrowding by foreign refugees, also mentioned by Aristophanes in The Acharnians) ${ }^{8}$ and the probable source (Africa). The population is estimated to have trebled or quadrupled during the siege, from a prewar population of around 100-150,000 people (60,000 citizens, 25,000 metics and 70,000 slaves at most) to 300-400,000 within the 'long walls' of Athens, which encompassed the polis of Athens, the port of Piraeus, and the road between them (Morens \& Littman 1992). ${ }^{9}$

Thucydides' account establishes commonalities with other significant historical epidemics - the breakdown of laws and society, a loss of belief in religion, the rebellion of suppressed members and groups in society, and the disintegration of familial relationships as self-preservation became the first goal. However, there is a crucial difference here. During epidemics, outside or minority groups are frequently blamed for the pestilence. In Athens, however, the pestilence was initially blamed on the poisoning of water sources in Piraeus by the Peloponnesian invaders (Alford 1998). But this theory was later discounted when the pestilence moved into the city, and water sources in the port were not connected to the city wells, which were also on higher ground.

Even so, the new influx of population could not have gone unnoticed as a possible contributing factor in the epidemic's spread. Thucydides noted the overcrowding caused by the movement of the rural population and refugees within the walls to avoid the Spartan siege worsened the disease while the more sparsely-inhabited countryside suffered much less. The density of inhabitants within the city walls could have varied from 25,000 to 100,000 per square mile, exacerbating the effects of any disease spread by person-toperson contact (Morens \& Littman 1992). Possibly, the Athenians - whose imposition of quarantines, both officially and spontaneously, indicates they were aware of the connection between overcrowding and the spread of the disease - avoided a much higher mortality rate by moving their cattle to Euboea rather than taking them into the city and housing them near people. When the Romans housed their cattle near people during a similar epidemic in 433, they suffered a higher mortality rate (Couch 1935).

\section{Thucydides' History of the Peloponnesian War}

Thucydides (460-395 BCE) was a wealthy Athenian citizen and general who fought in the war and also survived the plague. He began his History of the Peloponnesian War in 431 and left it unfinished upon his death. His is the only contemporary account of the plague. Though other first-hand accounts survive of the war, and other ancient writers mention the plague, the latter appear to base their accounts on Thucydides (Commager 1957). He is, therefore, the only known eyewitness account of the plague.

8 Vickers (1991 and 1997: p. 196) sees in the bed-bug scene of the Clouds an evocation of the suffering of the victims. A depiction of the Theban plague is found in Sophocles' Oedipus Rex.

$9 \quad$ From figures calculated by Gomme (1933: pp. 22, 44). 
Until the past few decades, Thucydides' account has been accepted at face value. Recent scholarship has become more critical of the account, noting evidence of Thucydides' hostile attitudes toward religion and women - religion being considered the province of women - with his hostility apparent in the very way he describes both the war and the plague (Wiedemann 1983). One problem in studying Thucydides is that his 'objectivity' appears to be based on his belief in contemporary 'atomists', who believed in cause and effect (Alford 1998). Modern science deals greatly in cause and effect within the natural world, while disbelieving any religious or other supernatural cause and effect. As such, scientists and even historians have focused more on any causes of the plague - which were understandably vague and speculative for Thucydides - and less on what Thucydides perceived to be the plague's chief 'effect', namely social unrest.

Thucydides gives us a narrative that seems clear and straightforward, although his account of the plague ignores many elements he himself wrote about elsewhere. The refugees from other city-states and the countryside, who provided the most proximate cause of the plague's remarkable and rapid spread, were only there because of the war itself. The plague comes from a foreign land then it must have come with the refugees. Some Athenians gave credence to the legend that a prophecy had favored a victory by the Spartans (Thuc. 2.54). Since Sparta refused to allow permanent immigrants and also did not suffer much from the plague, it can be seen how this might even affect the domestic attitudes of Athens. We are warranted in asking: did the plague cause the social unrest, or were there other, perhaps more dominant, causes for the social change in Athens? War often causes social unrest, too, and often, the unrest is more permanent than that caused by disease.

Thucydides makes a point of saying that Athenians continued with their funeral rites throughout the war, except during the plague (Lateiner 1977). Why would he do this? It could be the dichotomy in Greek thought between the open, cosmopolitan, democratic rule of Athens and the closed, xenophobic rule of Sparta. Though the cities were rivals, some Athenians (like Xenophon) greatly admired the Spartan military code, though the Spartans do not appear to have returned the favor (Powell 2001: pp. 222, 224). Athens shared with Sparta a love of 'freedom' - the right of each city-state to live as its citizens wished - and also an admiration of military prowess combined with pious respect for the gods: the two city-states had made ready allies when they fought together against the Persians half a century earlier. Thucydides was less enthusiastic than Xenophon about the Spartans, disparaging their intelligence, but nevertheless viewed them as neighbors and rivals rather than unrelated foreigners like the Persians (Powell 2001: pp. 97f.). As such, Thucydides does not present the war as the source of social ills the way he presents the plague.

Thucydides also couches the negative changes in terms of how they violate Athenian culture in some way. Familial bonds are ignored. Religion is abandoned as useless (because belief or piety have nothing to do with survival). Most of the educated physicians die, demonstrating that education and intelligence cannot prevail against the plague, nor against the discord and descent into superstition that followed in its wake (Thuc. 2.47). 
Thucydides appears to struggle with the paradox that Athens could be rich, powerful, open to innovation and new influences (as in Pericles' funeral speech near the beginning of the war), yet is more severely punished by the epidemic than other city-states. This is not surprising. A look at the way Athens and other Greek states dealt with the problem of the metic (the immigrant) shows that the Greeks were ambivalent about the metics. Very few metics lived in Sparta, which had closed itself off from most outside influences. A large number of metics, however, resided in Athens, which had opened itself wide to foreign trade, even as it still feared losing its native character and influence (Whitehead 1977: pp. 154f.).

The plague was a demographic disaster for the city. The number of citizens who were killed among the third of the total population lost (some of those metics and slaves) is unknown. There is evidence that this epidemic changed the demographic balance between citizen and metic, and resulted in further tightening of restrictions against metics that had begun in the 450s. A law passed in 451, restricting Athenian citizenship to only those born of Athenian citizens, ${ }^{10}$ was reenacted in 403, the year after the war ended (Roy 1999). Hostilities toward alien residents, rather than abating, only increased after the war.

It would appear that the long term reaction of the Athenian citizenry to the losses in the plague and the war was to tighten the rules of citizenship rather than open them up and increase citizenship numbers by allowing the richer and more industrious metics entry into their ranks. This is perhaps explained by Thucydides' estimate that it took 15 years (from the initial outbreak of the plague) for the city to recover its population (Couch 1935). The Athenians appeared concerned that they needed to conserve their citizenry, but were not convinced that they needed to open up citizenship again (as they had three quarters of a century earlier) to non-Athenians. Further, they had the example of the victorious Spartans, who refused to open their ranks to the point where they went into permanent population decline in the fourth century, but only after they succeeded in humbling Athens during the war and proving themselves a dominant force in Greek politics (Cawkwell 1983).

Thucydides goes into little detail about how the plague affected people of different class or gender. Many of the inhabitants who came into the city from the countryside were agricultural slaves, for example, with less-healthy diets that might have made them more vulnerable to the plague (Jameson 1977/1978). As an aristocratic citizen, Thucydides had little interest in the lower classes. Still, Thucydides makes it clear that no class fully escaped.

\section{Archaeological and epidemiological evidence of the Plague}

Other sources (such as Aristophanes) exist for the war and the conditions of the siege, if not the plague itself, as well as the war's aftermath. Many epitaphs, laws and legal cases also survive, showing the evolution of the treatment of metics over the fifth and fourth

10 The source for Pericles' citizenship law is the Constitution of the Athenians, attributed to Aristotle. 
centuries (Whitehead 1977: pp. 27-68). Excavations have also clarified the unique architecture of the long walls and the way Athenians lived and built their housing, as well as the construction of the wells (first believed to have been poisoned by the besieging army) and the final resting place of many victims (who congregated at the wells in desperate thirst near the end of their lives) (Alford 1998). Some historians have even analyzed Thucydides' terms in describing the plague and compared them to contemporary lay and medical terms (Page 1953). ${ }^{11}$

Corroboration for the plague itself did not come until 1994, during the excavation of a mass grave (ca. 430-420 BCE) of approximately one hundred and fifty bodies in one area of a cemetery. This was not an impromptu burial, at least at first. Initial burials at the bottom of the gravesite were laid out carefully and included pot burials. However, in later burials, the bodies were essentially tossed into the grave rather than laid out as before. The only exceptions were the pot burials of eight children. Grave goods consisted of scattered vases of poor quality, most of which dated from the period of the Athenian plague. Mass burials of uncremated bodies were rare in Classical Greek society and linked with times of pestilence, indicating that this was a burial from one of the plague outbreaks (Papagrigorakis et al. 2006).

The carelessness of the later burials and the paucity of grave goods support Thucydides' observations about the breakdown of burial customs. The author of a paper on the excavation also notes that Thucydides' claims that military burials, even late in war or in the face of defeat, were neat and in concurrence with religious piety and proper death rites, is borne out by archeological evidence, from which this burial (like other known pestilence burials) diverges significantly (Papagrigorakis et al. 2006). One aspect differs from Thucydides' account: Infants were buried carefully and in accordance with rites, even when adults were not.

DNA analysis of pulp from the roots of teeth found in the skeletons at the site also indicated a possible cause for the epidemic - typhoid. On the one hand, this does not connect well with the archeological evidence regarding Athenian wells not being connected to the wells in Piraeus, since typhoid is a waterborne pathogen. On the other hand, this could also tie in with Thucydides, in that he mentions afflicted people gathering around wells and trying to throw themselves in. This could have contaminated the water of a particular well, with subsequent victims contaminating other wells in a chain of causation.

\section{The definitions of citizens and non-citizens in ancient Greece}

As the largest and most cosmopolitan Greek city-state in the fifth century, Athens saw much immigration from other parts of Greece. While democracy was a common government in the Greek city-states at the time, the voting citizenry was limited to freeborn males who had been born in that city-state. Freeborn immigrants from other city-states,

11 More recent references are Craik (2001) and Connor (1985). See also fn. 6. 
of as little residential time as a month, were known as 'metics' (metoikoi). The term first appears in early fifth century documents (Whitehead 1984: p. 7). Metics were immigrants from other city-states of Greece, usually merchants or artisans. A male metic (like a former slave) might buy his way into the citizenry and a female metic might marry into it. Otherwise, they remained citizens of the city-state from which they had emigrated and could only hold rights in their home city (oikos), not Athens. Metics lived in most Greek cities, especially Athens. However, Athenian citizens in the early fifth century became concerned about the huge influx of immigrants from other areas of Greece following the Persian wars in the 490s and 480s (Bakewell 2008/2009).

This situation reached a crisis point in 451, when the statesman Pericles imposed an immigration law that forbade all but Athenians born of two Athenian citizens from becoming citizens and therefore partaking of the benefits of Athenian politics and imperial hegemony. This immediately reduced the power and authority of metics in Athens and made intermarriage no longer a way for metics to become Athenian. In essence, it created an endogamous ethnic upper class. Since metics constituted from one/fifth to one/half of free Athenians at the time, the law was clearly a response to ethnic fears in native Athenians that they would be overwhelmed and replaced by foreigners, especially via marriage of young metic women to Athenian men (Stewart 1995).

It also became much more difficult for a metic to become a citizen. He had to do so by paying large sums of money to the city and contributing to great works. It is unknown if a metic who bought his status in this way might have it applied as well to his wife and his children, though it seems likely. Otherwise, any previous marriage would become null and void upon his acquiring citizenship, making his children illegitimate. Metics usually could only become citizens late in life and after working for many years on behalf of the city (Carey 1991).

While women of the metic class were called 'metics' and of the citizen class 'citizens', Athenian women did not possess citizenship rights. Even so, a metic woman also lost the ability to marry into the citizen class and confer her father's status on her children due to the law. Pericles himself lived to regret his legislation when he took a metic mistress and had to plead with the Athenian citizens to legitimize his children (Stewart 1995).

The period, perhaps not coincidentally, saw a conflation of the mythical female Amazons with the Persians who had invaded Greece in the 480s. Ethnic tensions also appeared in two plays during the war, Euripides' Medea (431) and Hippolytus (428). These two plays portray marrying a foreign woman as an unwise idea that leads to tragedy. Here, foreigners are specifically codified as females (weak and unruly) and barbarians, who bring misfortune to Athens (Stewart 1995).

\section{Non-citizens in Athens after the Plague}

While the accession of a metic to Athenian citizenship was not impossible or unknown, it was also rare and greatly discouraged, more so in the fourth century than the fifth. As such, there are many injunctions and court cases in the historical records against metics 
passing themselves off as citizens. These appeared to increase after the law of 451 and restrictions did not relax following the plague or the war. Since some metics became quite wealthy (due to a major reason for immigration being to seek engagement in Athenian free trade), they found ways to pay off officials and hide their original status, becoming de facto citizens.

However, the price of discovery was high, usually reduction to slave status. Even an innocent metic might suffer that fate without a powerful patron in the Athenian citizenry. Metics were also more subject to military draft and taxation. While male metics were not legally excluded from testifying in Athenian courts (the way women, children and slaves were), most witnesses in court cases were citizens. Nor could metics act as jurors in trials. Most importantly, they could not own land, the main traditional source of wealth for Athenian citizens (Whitehead 1977: pp. 69-108). This did not stop immigration to Athens, but it did result in a semi-enfranchised third class between citizens and slaves, which encouraged some metics to leave. There was, for example, a decline in the Attic pottery industry during the war, which had not occurred in previous wars, probably due to the new restrictions and increased xenophobia in native Athenians (MacDonald 1981). Metics were a minority, but not a small or unimportant one.

Citizenship in the fourth century did not necessarily create security for a former metic and his children. Apollodorus, a fourth century writer, was frequently in litigation with others, including his step-father (Johnstone 2003). His father had been a metic (Carey 1991). Many of Apollodorus' lawsuits involved cases that impinged on his honor as a citizen and may show paranoia over being the descendant of a metic, an uncertainty about his own citizenship, which right he had to continually defend against other, 'real' citizens. The position of metics in the fourth century (after the plague) was more unstable than that in the fifth century (before the plague) and appears to be reflected in the anxieties of metics, former metics and their descendants.

It is probable that other changes in Athenian society affected metic status, including the Pelopponesian War itself. Nor was the exclusion entirely one-sided. In epitaphs, both military and civilian, metics chose not to identify themselves as foreigners or metics of Athens, but as residents of their home city, no matter how many generations removed (Meyer 1993). However, the permanence of the 451 legislation and the tightening of restrictions against metics indicate that the war and the plague contributed to a decline in metic status in Athens.

\section{Conclusion}

Though only one literary source for the Athenian Plague exists (Thucydides), and he does not specifically address the change in attitudes toward metics, it is possible to reconstruct the Athenians' reaction to the epidemic, and their subsequent evolution of attitudes toward foreigners. The position of metics in Athens was initially better than in other city-states, but it was legally and socially uncertain. It became more so in the wake of the plague, in the fourth century, with the metics permanently losing the power 
to become citizens (and perhaps the will to achieve Athenian citizenship) as Athens also lost power and prestige, and the need to expand. Because they had no direct and individual political power, and lacked the right to buy the most secure and important form of wealth (land), metics had no means to increase their legal or political rights in the city-state of Athens. The events of the war and the plague tilted the fragile balance increasingly against them. Though it is difficult to say from this vantage point how much of this decline discouraged metics from settling in Athens, the resultant decline in rights (and lack of interest of metics in identifying as metics) in the fourth century indicates that the metic class was never properly integrated into Athenian society. What power metics had in the fifth century both declined and became less valuable in the fourth. Much of this occurred because of a war between Greece's two most powerful city-states and the plague that may have determined which side won.

\section{Bibliography}

Alford, E. M. (1998). Thucydides and the Plague in Athens: The Roots of Scientific Writing. Written Communication, 15, 361-383.

Bakewell, G. (2008/2009). Forbidding Marriage: Neaira 16 and Metic Spouses at Athens. The Classical Journal, 104(2), 97-109.

Butterfield, D. (2014). Lucretius auctus? The Question of Interpolation in De rerum natura. In J. Martínez (Ed.), Fakes and Forgers of Classical Literature. Ergo decipiatur! (pp. 15-42). Leiden: Brill.

Carey, Ch. (1991). Apollodoros' Mother: The Wives of Enfranchised Aliens in Athens. The Classical Quarterly, New Series, 41(1), 84-89.

Cawkwell, G. L. (1983). The Decline of Sparta. Classical Quarterly, 33, 385-400.

Commager, H. S. (1957). Lucretius' Interpretation of the Plague. Harvard Studies in Classical Philology, 62, 105-118.

Connor, W. R. (1985). Thucydides (2. ed.). Princeton: Princeton University Press.

Couch, H. N. (1935). Some Political Implications of the Athenian Plague. Transactions and Proceedings of the American Philological Association, 66, 92-103.

Craik, E. M. (2001). Thucydides on the Plague: Physiology of Flux and Fixation. The Classical Quarterly, New Series, 51(1), 102-108.

Crawley, R. (Transl.). (1910). Thucydides: The History of the Peloponnesian War. London: Dent.

Gomme, A. W. (1933). The Population of Athens in the Fifth and Fourth Centuries B.C. Oxford: Blackwell.

Holladay, A. J., \& Poole, J. C. F. (1979). Thucydides and the Plague of Athens. The Classical Quarterly, New Series, 29(2), 282-300.

Hornblower, S. (1991). A Commentary on Thucydides (Vol. I). Oxford: Clarendon Press.

Jameson, M. H. (1977/1978). Agriculture and Slavery in Classical Athens. The Classical Journal, $73(2), 122-145$.

Johnstone, S. (2003). Women, Property and Surveillance in Classical Athens. Classical Antiquity, 22(2), 247-274.

Lateiner, D. (1977). Heralds and Corpses in Thucydides. The Classical World, 71(2), 97-106. 
Laurin, J. R. (2005) Women of Ancient Athens. Victoria (BC): Trafford Publishing.

Longrigg, J. (1980). The Great Plague of Athens. History of Science, 18, 209-225.

MacDonald, B. R. (1981). The Emigration of Potters from Athens in the Late Fifth Century B.C. and its Effect on the Attic Pottery Industry. American Journal of Archaeology, 85(2), 159-168.

Meyer, E. A. (1993). Epitaphs and Citizenship in Classical Athens. The Journal of Hellenic Studies, 113, 99-121.

Morens, D. M., \& Littman, R. J. (1992). Epidemiology of the Plague of Athens. Transactions of the Philological Association, 122, 271-304.

Orwin, C. (1988). Stasis and Plague: Thucydides on the Dissolution of Society. The Journal of Politics, 50(4), 831-847.

Page, D. L. (1953). Thucydides' Description of the Great Plague at Athens. The Classical Quarterly, New Series, 3(3/4), 97-119.

Papagrigorakis, M. J., Yapijakis, Ch., Synodinos, Ph. N., \& Baziotopoulou-Valavani, E. (2006). DNA examination of ancient dental pulp incriminates typhoid fever as a probable cause of the Plague of Athens. International Journal of Infectious Diseases, 10, 206-214.

Parry, A. (1969). The Language of Thucydides' Description of the Plague. Bulletin of the Institute of Classical Studies of the University of London, 16, 106-118.

Perrin, B. (Transl.). (1916). Plutarch's Lives. Cambridge, MA: Harvard University Press.

Powell, A. (2001). Athens and Sparta: Constructing Greek Political and Social History from 478 BC. (2. ed.). London: Routledge.

Roy, J. (1999). Polis and Oikos in Classical Athens. Greece Ev Rome, Second Series, 46(1), 1-18.

Rubincam, C. (2004). Thucydides and Defoe: Two Plague Narratives. International Journal of the Classical Tradition, 11(2), 194-212.

Salway, P., \& Dell, W. (1955). Plague at Athens. Greece Ẽ Rome, Second Series, 2(2), 62-70.

Stewart, A. (1995). Imag(in)ing the Other: Amazons and Ethnicity in Fifth-Century Athens. Poetics Today, 16(4), 571-597.

Vickers, M. (1991). A contemporary account of the Athenian plague? Aristophanes Clouds 694734. Liverpool Classical Monthly, 16, 64.

Vickers, M. (1997). Pericles on Stage: Political Comedy in Aristophanes' Early Plays. Austin: University of Texas Press.

Whitehead, D. (1977). The Ideology of the Athenian Metic. Cambridge, U.K.: Cambridge Philological Society.

Whitehead, D. (1984). Immigrant communities in the classical polis: some principles for a synoptic treatment. L'Antiquité Classique, 53, 47-59.

Wiedemann, Th. (1983). Thucydides, Women and the Limits of Rational Analysis. Greece and Rome, 30, 163-170.

Javier Martínez / martinez@uniovi.es

Filología Clásica

Facultad de Filosofía y Letras, Universidad de Oviedo

Teniente Alfonso Martínez, s/n, ES-33011 Oviedo, Spain 